\title{
ВСЛЕД ЗА ЗОЛОТЫМ ОЛЕНЕМ... (к юбилею А.С. Ермолаевой)
}

\section{(C) 2018 г. Т.Н. Лошакова}

В статье обозначены основные вехи творчества юбиляра - А.С. Ермолаевой. Еще в студенчестве Антонина Сергеевна решила стать археологом. В череде полевых сезонов с участием юбиляра исследовались различные эпохи древней истории Казахстана. В настоящее время Антонина Сергеевна успешно занимается разработкой вопросов, связанных с изучением металла и металлопроизводства на поселениях Сарыарки. География археологических интересов юбиляра широка и охватывает пространство от Алтая до Каспия.

Ключевые слова: археология, А.С. Ермолаева, археолог, памятники

Есть ли в обычной жизни романтики?

Кто они? Где? И какие они?

Да те, кто живут по макушку счастливые Мечтами, любимым своим трудом, Те, кто умеет найти красивое Даже в будничном и простом.

В 1968 г., Усть-Каменогорская киностудия сняла фильм о работе археологической экспедиции Ф.Х. Арслановой, в которой принимали участие студенты Усть-Каменогорского пединститута. На архивных кадрах мелькают лица студентов, среди которых легко узнать Антонину Сергеевну Ермолаеву. Это был первый опыт археологических исследований, первые шаги, которые стали началом долгого профессионального пути.

Родилась Антонина Сергеевна на кордоне Чанды (в наст. вр. Бескарайгайский р-н, ВКО). Детство было таким же, как у всех: семья, школа, друзья. Но, судя по рассказам Антони- ны Сергеевны, именно в семье было привито трудолюбие, серьезное отношение к делу, ответственность.

В 1966 г., выдержав большой конкурс, Антонина Сергеевна поступает в Усть-Каменогорский педагогический институт на исторический факультет, который блестяще окончила в 1970 г. После окончания Института была работа в средней школе поселка Богенбай, в государственном архиве Усть-Каменогорска, на кафедре философии строительно-дорожного Института. Но все это было лишь жизненной необходимостью, а сердце стремилось к археологии, которой удавалось посвящать лишь летние месяцы. 
Тогда проводились исследования в Центральном Казахстане археологической экспедицией, которой руководил М.К. Кадырбаев. Работы велись на поселениях Тагыбайбулак, Атасу, а также памятниках на реке Илек - могильниках Бесоба и Сынтас. Большой этап работ был посвящен исследованиям в зоне строительства Шульбинской ГЭС в 1977 г. Затем были работы в Мангышлакской области в составе экспедиции проектной группы «Казреставрация» в качестве археолога. В тот год осуществлялись обмерные работы на некрополях Сенек и Шопан-ата. Но интерес к археологии был настолько велик, что в перерыв, в самую жару, Антонина Сергеевна исследовала окрестности, осматривая памятники археологии. Позже были работы в урочище Тамгалы, где с А.Г. Максимовой исследовали курган и совместно с А.Н. Марьяшевым изучали знаменитые петроглифы. И хотя особый интерес у исследователя вызывали памятники кочевников, работать приходилось на памятниках разных периодов - на крепостной стене средневекового городища Туркестан, на комплексах петроглифов в Чулакских горах и в Джунгарии, на палеолитической стоянке Лахути 2 и городище Хульбук в Таджикистане, участвовать в археологических разведках в Казахстане.

Попасть на работу в отдел археологии Института истории, археологии и этнографии им. Ч.Ч. Валиханова АН КазССР было в ту пору нелегко, и для Антонины Сергеевны это стало возможным только в 1979 г. Несмотря на огромный опыт, на первых порах она могла работать только лаборантом в ЮКАЭ. Начиная с 1981 г., Антонина Сергеевна руководила работами отрядов Шульбинской, Центрально-Казахстанской, Семиреченской, Восточно-Казахстанской ар-

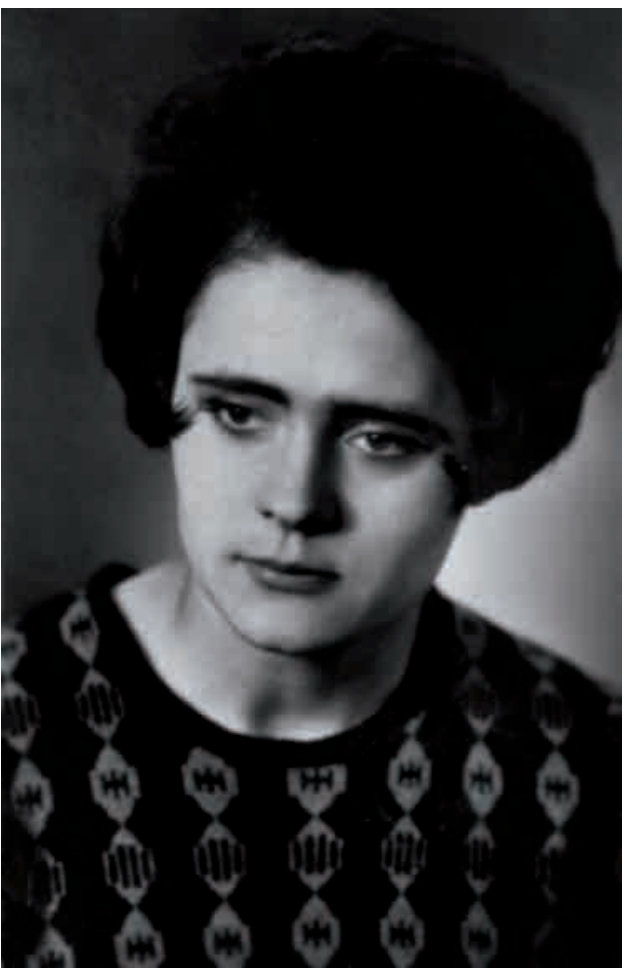

Рис. 1. Антонина Сергеевна Ермолаева

Fig. 1. Antonina S. Ermolaeva

хеологических экспедиций. В 1983 г. становится хранителем особой кладовой ИИАЭ, хранителем экспозиции в музее археологии и позже, в 1985 г., хранителем фондов музея. В штат ИИАЭ Антонина Сергеевна была зачислена только в 1984 г., где до сих пор и работает вот уже 39 лет.

За это время было совершено немало увлекательных экспедиций, исследовалось большое количество интересных памятников - могильники Измайловка, Тарасу, Берел, Аралтобе, Иманкара, поселения Аиртау, Токсанбай, Талдысай, Серектас и др.

Список трудов у юбиляра внушительный - более 60 работ, в числе которых монография, книги-альбомы, участие в коллективных монографиях, а также статьи, изданные в Казахстане, ближнем и дальнем зарубежье.

На самом деле этапы любой трудовой биографии выглядят доволь- 
но сухо. В реальности же это увлекательные полевые сезоны и интересные их результаты, встречи с разными людьми, смешные истории, но прежде всего тяжелый труд. Так сложилось, что проводить археологические раскопки Антонине Сергеевне приходится в основном в регионах с нелегким климатом: жара днем и холод ночью, бесконечная роза ветров в Западном и песчаные бури в Центральном Казахстане, все это она стойко переносит. Когда начинаются сильные ветра на поселении Токсанбай так, что даже глаза открыть порой невозможно и хочется в палатку, потому что только там и можно вздохнуть, Антонина Сергеевна продолжает упорно расчищать раскоп, бесстрашно лезет на самый крутой склон и даже мои напоминания о ждущих дома детях ее не останавливали.

Впервые на поселение Токсанбай на Устюрте Антонина Сергеевна, вместе с 3. Самашевым, приехала в 1997 г. и с тех пор, на протяжении многих лет, работала на памятнике. Многоуровневое поселение, со сложными строительными конструкциями, алтарными нишами, технологическими очагами было сложным в исследовании, но очень интересным. Многометровые напластования культурных слоев, в которых странным образом перемешались предметы, относящиеся к разным культурам, вызывали много вопросов, но и в благодарность за упорство в исследовании дарили необычайные находки - псалии, впервые найденные на этой территории, навершие в виде головы лошади, керамика со сложным орнаментом. Изучая материалы поселения, именно Антонина Сергеевна сделала предположение, что на формирование токсанбайского культурного феномена повлияли носители иванобугорской культуры, памятники которых были выделены А.Т. Синюком и В.Д. Березуцким в Доно-Волжском регионе [Синюк, Березуцкий, 2001].

О поселении Талдысай хочется сказать особо. На этом памятнике Антонина Сергеевна работает много лет. Совместно с челябинским археологом И. Русановым ею была реконструирована печь и экспериментально опробован способ плавки меди. В ее рассказах об исследованиях на Талдысае меня всегда поражало как легко и с какой увлеченностью она говорит о химических процессах, о сульфидных и окисленных рудах, шлаках, плавках... И в этом проявляется характер Антонины Сергеевны, которая всегда глубоко вникает в проблему и дотошно изучает материал. Поэтому с ней можно говорить о памятниках практически любой археологической эпохи, ну, может, за исключением палеолита, хотя в арсенале Антонины Сергеевны и участие в экспедициях В.А. Ранова, исследовавшего памятники древнекаменного века в Таджикистане. В ее рассказах о памятниках, на которых она работала или бывала, можно всегда услышать, что это «очень интересно».

Антонине Сергеевне можно позавидовать в том, что ей довелось поработать с людьми, которые сейчас уже стали легендами археологии Казахстана, и вклад в науку их бесспорен - К.А. Акишев, А.Г. Максимова, Ф.Х. Арсланова, А. Чариков, М.К. Кадырбаев, К.М. Байпаков, А.Н. Марьяшев, Ю.А. Мотов, С.А. Берденов, Т.М. Тепловодская, 3. Самашев, Ж. Курманкулов, Э.Ф. Кузнецова.

Творческий путь ученого - это всегда вопросы и поиск на них ответа. Немногие, преодолев трудности, остаются в науке и становятся признанными специалистами. Антонина Сергеевна из числа тех, кто, несмотря на тяготы 1990-х, все же осталась преданной археологии. 
В жизни каждого человека есть люди, которые оказывают заметное, подчас решающее, влияние на формирование его профессиональных качеств, характера и мировоззрения. И особенно, как мне кажется, счастлив тот, кому встретился человек, умеющий принести не только знания, но еще любовь и доброту. Мне очень повезло! Вот уже 19 лет я имею возможность совместно работать и учиться у внимательной, обаятельной женщины, оптимистки и прекрасной души человека. У неё есть все - талант, душевная теплота, ум, чуткость, терпение, неиссякаемая энергия и оптимизм.

После трудового дня в поле, коротая вечерами время, мною было услышано много рассказов и историй, веселых и поучительных. А еще меня поразил ее тортик на сковороде, который она пекла на Аралтобе, практически из ничего. С удовольствием вспоминаю, как на поселении Токсан- бай в 1999 г., приехав тогда на неделю, мы чистили и резали овощи на борщ ночью, под светом фар грузовика, потому что днем не было времени, а позже также ночью жарили шелпеки. Там же на Токсанбае читали интервью ее дочери Даны, где она рассказывала, что хочет быть археологом, а «мама говорит, только через ее труп». И во всем, что не происходит, всегда Тоня находит положительный момент и с юмором все комментирует. Это в ней меня всегда восхищает.

Энергии и внимания Антонины Сергеевны хватает не только на семью, где выросли две замечательные дочери и сейчас подрастает внучка, но и на коллег. В ее кабинете, за чашкой чая, за беседой всегда ощущаешь душевное тепло и поддержку. Она не скупится поделиться тем, что знает и умеет.

Восхищение вызывает ее большое доброе сердце. Собаки, которых

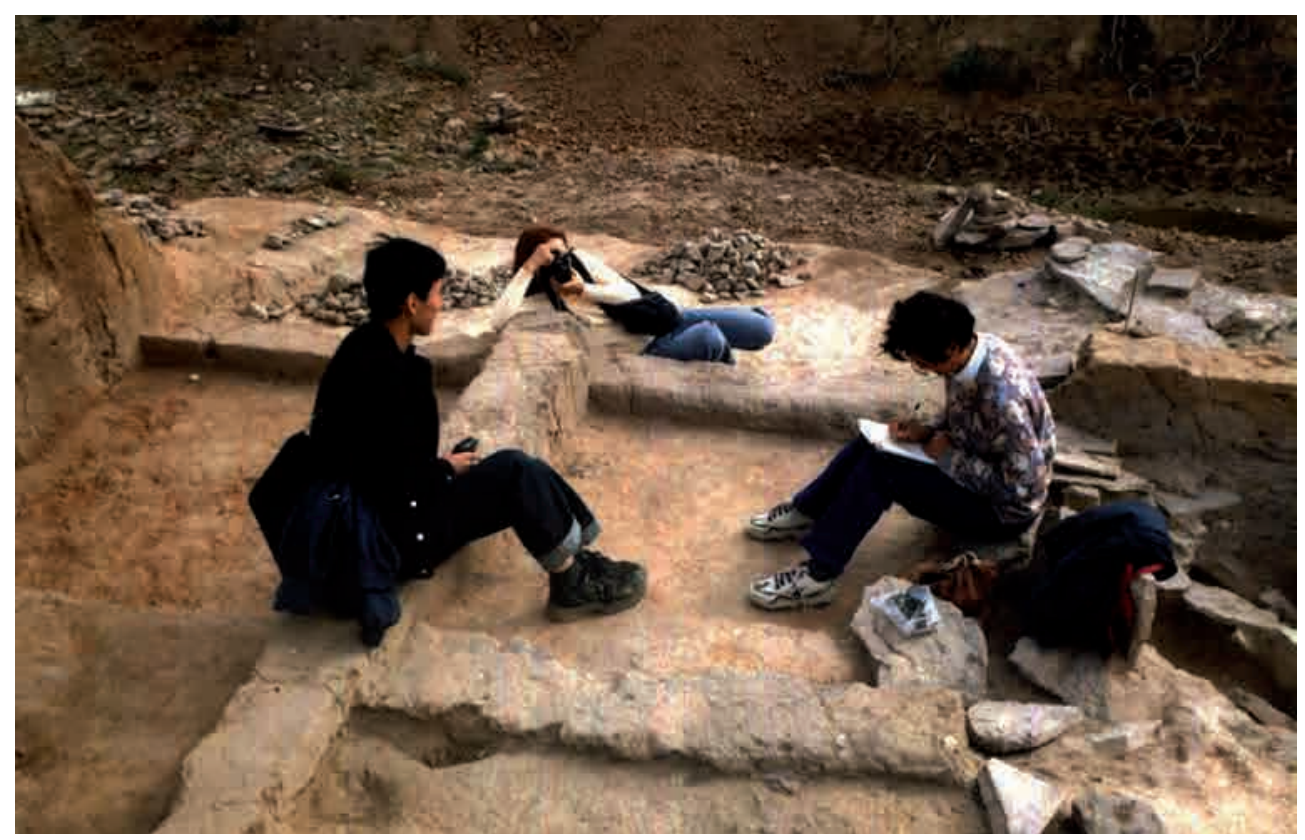

Рис. 2. С журналистами из Жезказгана на поселении Талдысай. Фото А.Е. Ержановой. 2002 г.

Fig. 2. With journalists from Jezkazgan on Taldysay. Photo by A.E. Erjanova, 2002 
Лошакова T.H. Вслед за золотым оленем...

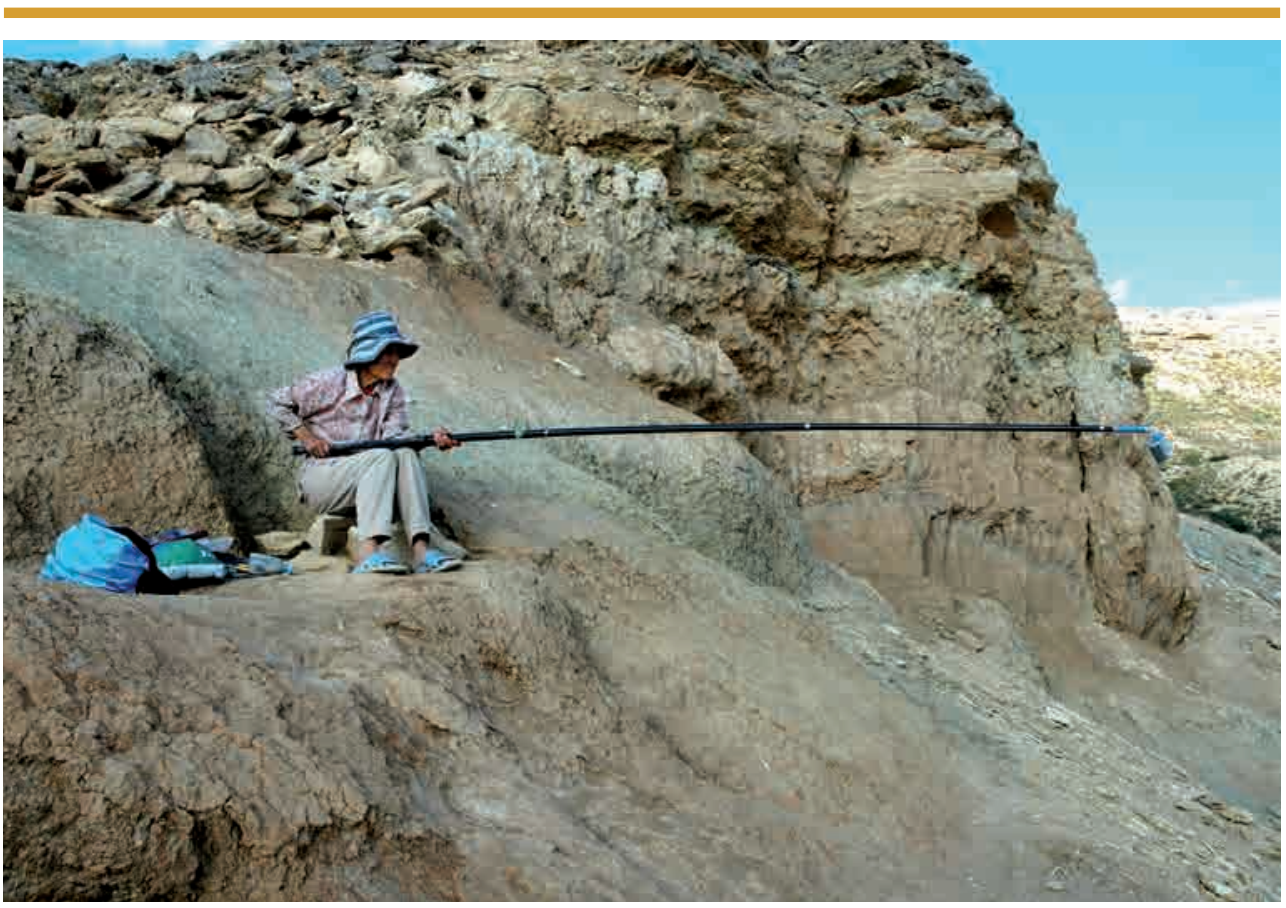

Хочу быть археологом

С диагнозом «по фазе»,

Чтобы врачи за голову,

Узнав, хватались сразу.
Хочу быть археологом,

Науке быть полезною,

Чтоб жизнь прожить свою

Назло всем интересную...

Рис. 3. В редкие часы досуга на Устюрте. Фото Т.Н. Лошаковой, 2015 г.

Fig. 3. At the rare leisure hours on the Ustyurt. Photo by T. Loshakova, 2015

она подбирает, лечит и устраивает в хорошие руки, птицы у Института, которых она подкармливает, летучие мыши и жабы на Аралтобе, удавы на склонах Устюрта, любая живность всегда находит у нее защиту, на всех у нее находятся силы и внимание.

В том самом, фильме, снятом в 1968 г., Фирая Хабибуловна, рас- сказывая о раскопках и показывая находки, говорит школьникам о том, что нужно изучать и знать историю, и тогда золотой олень поведет их за собой и откроет им свои тайны. Антонина Сергеевна, как мне кажется, однажды избрав путь, идет за своим золотым оленем, и много тайн древних уже открыто, и сколько еще впереди...

\section{ЛИТЕРАТУРА}

1. Синюк А.Т., Березуцкий В.Д. Мостищенский комплекс древних памятников (эпоха бронзы - ранний железный век). Воронеж: Воронежский государственный педагогический университет, 2001. 192 с. 


\section{Список основных публикаций А.С. Ермолаевой}

Монография:

Памятники предгорной зоны Казахского Алтая (эпоха бронзы-раннее железо). Алматы: Институт археологии им. А.Х. Маргулана, 2012. 238 с. Отв. ред. 3. Самашев.

\section{Книги-альбомы:}

Наскальные изображения урочища Тамгалы. Алма-Ата: «Онер», 1985. 143 с. (в соавт. с Максимовой А.Г., Марьятевым А.Н.).

Древние сокровища Казахского Алтая. Алматы: «Онер», 2008. 200 с. (в соавт. с Самашевым 3., Куш Г.А.).

Поселение Талдысай - памятник древней металлургии. Алматы: Институт археологии им. А.Х. Маргулана, 2012. 132 с. (в соавт. с Курманкуловым Ж., Ержановой А.Е.) (на каз. и рус. яз.).

\section{Разделы в коллективных монографиях:}

Памятники эпохи бронзы // Археологические памятники в зоне затопления Шульбинской ГЭС. Алма-Ата: изд. «Наука» АН КазССР, 1987. С. 24-63 (в соавт. с Максимовой А.Г.).

Памятники переходного периода от эпохи бронзы к раннему железу// Археологические памятники в зоне затопления Шульбинской ГЭС. Алма-Ата: изд. «Наука» АН КазССР, 1987. С. 64-94.

Характеристика раскопанных объектов нижнего слоя поселения Талдысай // Комплекс памятников в урочище Талдысай. Алматы: Институт археологии им. А.Х. Маргулана, 2013. Т. 1. С. 135-167 (в соавт. с Ержановой А.Е.).

Казахский Алтай в I тысячелетии до н.э. // Казахстан в сакскую эпоху: коллективная монография.Отв.ред.А.З.Бейсенов. Алматы:Институтархеологииим. А.Х.Маргулана, 2017. С. 101-156 (в соавт. с Самашевым 3., Джумабековой Г.С.).

Исследования поселения Мыржык // Археологические исследования в северной Бетпакдале: коллективная монография. Отв. ред. А.З. Бейсенов. Алматы: Институт археологии им. А.Х. Маргулана, 2017. С. 37-67 (в соавт. с Бейсеновым А.З., Курманкуловым Ж.).

\section{Статьи:}

Курганы Бесобы и Сынтаса //АО-1976. М.: «Наука», 1977. С. 515-516 (в соавт. с Кадырбаевым М.К., Курманкуловым Ж.К., Воронцовой Г.Г.).

Новые петроглифы урочища Тамгалы // ВАН КазССР. 1978. № 8. С. $50-55$ (в соавт. с Марьямевым А.Н., Мотовым Ю.А.).

Памятники кимаков левобережья Иртыша // Этническая история тюркоязычных народов Сибири и сопредельных территорий: тез. докл. обл. научн. конф. по антропологии, археологии и этнографии. Омск: ОмГУ, 1984. С. 143-144 (в соавт. с Арслановой Ф.Х.).

Исследования в Восточном Казахстане на левом берегу Иртыша // AO-1984. М.: «Наука», 1985. С. 509-510.

Поселение древних металлургов VIII-VII вв. до н.э. на Семипалатинском правобережье Иртыша // Вопросы археологии Казахстан. Алматы-М., 1998. Вып. 2. С. 39-46 (в соавт. с Ермоленко Л.Н., Кузнецовой Э.Ф., Тепловодской Т.М.).

Токсанбай - памятник древней городской цивилизации в казахской степи // Общественные науки в Синьцзяне. 1998. № 2. С. 18-24 (в соавт. с Самамевым 3., Тепловодской Т.М.).

Древнее горное дело и металлургия Восточного Казахстана (начало работ по КазахскоГерманскому проекту) // Вопросы истории и археологии Западного Казахстана. 2004. Вып. 3. С. 154-170 (в соавт. с Берденовым С., Самашевым 3., Штолльнером Т., Черны Я., Ермолаева А., Кущ Г.). 
Костяные псалии с поселения Токсанбай. К вопросу о комплексе колесничих населения Устюрта в эпоху бронзы // Вопросы истории и археологии Западного Казахстана. 2007. № 1. С. 53-55 (в соавт. с Самашевым 3., Ломаковой Т.Н.).

К проблемам металлопроизводства эпохи бронзы Казахстана // Мир Большого Алтая. 2017. № 3 (4). C. 481-493.

\section{Сведения об авторе:}

Лошакова Татьяна Николаевна - старший научный сотрудник, Институт археологии им. А.Х. Маргулана (Астана, Казахстан); loshakovat@mail.ru

\section{АЛТЫН БҰҒЫНЫН ІЗІМЕН... (А.С. Ермолаевының мерейтойына)}

\section{Т.Н. Лошакова}

Мақалада мерейтой иесі - А.С. Ермолаева шығармашылығының негізгі тұстары көрсетілген. Антонина Сергеевна студенттік кезден-ақ археолог боламын деп шешкен. Ол қатысқан маусымдық жұмыстар барысында ежелгі Қазақстан тарихының түрлі кезеңдері зерттелді. Қазіргі таңда Антонина Сергеевна Сарыарқа қоныстарындағы метал мен метал өндірісін зерттеу мәселелерімен табысты шұғылданып жүр. Оның археологиялық қызығушылықтарының жағырафиялық аясы кең және Алтайдан Каспийге дейінгі аралықты қамтиды.

Түйін сөздер: археология, А.С. Ермолаева, археолог, ескерткіштер

\section{ON THE MORROW OF THE GOLDEN DEER... (for the anniversary of A.S. Ermolaeva)}

\section{T.N. Loshakova}

The article identifies the main milestones of the hero of the day - A.S. Ermolaeva. Even in the studentship, Antonina S. decided to become an archaeologist. In a series of field seasons with the participation of the hero of the day, various eras of the ancient history of Kazakhstan were explored. Currently, Antonina S. is successfully engaged in the development of issues related to the study of metal and metal production in the settlements of Saryarka. The geography of the archaeological interests of the hero of the day is wide and covers the area from Altay to the Caspian Sea region.

Keywords: archaeology, A.S. Ermolaeva, archaeologist, monuments

\section{REFERENCES}

1. Sinyuk, A. T., Berezuckii, V. D. 2001. Mostishchenskij kompleks drevnih pamyatnikov (epoha bronzy - rannii zheleznyi vek) (Mostischensky complex of ancient monuments (Bronze Age - Early Iron Age)). Voronezh: Voronezh State Pedagogical University Publ. (in Russian)

\section{About the Author:}

Loshakova Tatyana N. Senior Researcher, A.Kh. Margulan Archeology Institute, Astana, Kazakhstan; loshakovat@mail.ru

Мақала туралы ақпарат / Информация о статье / Information about the article.

Жариялауға қабылданды / Принята к публикации / Accepted for publication: 23.10.2018. 